\title{
Pemanfaatan Media Video dan Market Plan dalam Mata Pelajaran IPA Pokok Bahasan Sistem Pencernaan Manusia Untuk Meningkatkan Hasil Belajar
}

\author{
Ida Hindasah \\ Magister Teknologi Pendidikan, Institut Pendidikan Indonesia, Garut, Indonesia \\ Email: idahindasah656@gmail.com
}

\begin{abstract}
Based on the results of observations made at Karangmulya I Public Elementary School and the author's experience that the material in the human digestive system of teachers is often difficult when teaching so that learning outcomes obtained by students are less satisfying. This study aims to (1) Develop learning by utilizing video media and market plan methods, (2) find out the development steps in learning, and (3) find out how far the merging of video media and market plan methods can improve student learning outcomes in Natural Sciences class VI subject of the human digestive system. The results of this study indicate that the learning media by utilizing video collaborated with the market plan method in science subjects the subject of the human digestive system shows an increase. This is evidenced by the acquisition of student values above the KKM. This learning work has been disseminated to colleagues especially in SDN Karngmulya I.
\end{abstract}

Keywords: Class VI Science;Human Digestion;Video Media and Market Plan

\begin{abstract}
Abstrak
Berdasarkan hasil observasi yang dilakukan di SDN Karangmulya I dan pengalaman penulis bahwa dalam materi sistem pencernaan manusia guru seringkali Kesulitan saat mengajarkanya sehingga hasil belajar yang diperoleh peserta didik kurang memuaskan. Penelitian ini bertujuan untuk (1) Mengembangkan pembelajaran dengan memanfaatkan media video dan metode market plan, (2) mengetahui langkah-langkah pengembangan dalam pembelajaran, dan (3) mengetahui sejauh mana penggabungan media video dan metode market plan dapat meningkatkan hasil belajar peserta didik pada mata pelajaran IPA kelas VI pokok bahasan sistem percernaan manusia. Hasil penelitian ini menunjukkan bahwa media pembelajaran dengan memanfaatkan video yang dikolaborasikan dengan metode market plan dalam mata pelajaran IPA pokok bahasan sistem pencernaan manusia menunjukan adanya peningkatan. Hal ini dibuktikan dengan perolehan nilai peserta didik di atas KKM. Karya pembelajaran ini telah didesiminasikan kepada rekan sejawat khususnya di lingkungan SDN Karangmulya I.
\end{abstract}

Kata kunci: IPA Kelas VI; Media Video dan Market Plan;Pencernaan Manusia.

\section{PENDAHULUAN}

Berbagai upaya telah dilakukan pemerintah dalam rangka mencerdaskan anak bangsa. Upaya yang dilakukan pemerintah antara lain mengupayakan pendidikan yang merata dan bermutu, menjangkau semua anak bangsa dengan proses pendidikan yang diatur dalam UU Nomor 20 Tahun 2003 tentang Sistem Pendidikan Nasional. Tujuan pendidikan nasional yaitu "mengembangkan potensi peserta didik agar menjadi manusia yang beriman dan bertaqwa kepada Tuhan Yang Maha Esa, berakhlak mulia, sehat, berilmu, cakap, kreatif, mandiri, dan menjadi warga negara yang demokratis serta bertanggung jawab" (UU Sisdiknas Pasal 3 UU No. 20 Tahun2003, 2003). Menurut Iif Khoiru Ahmadi \& Sofan Amri, (2011, p. 91) Pendidikan adalah salah satu bentuk perwujudan kebudayaan manusia yang dinamis dan sarat perkembangan. Oleh karena itu 
perubahan atau perkembangan pendidikan sejalan dengan perubahan budaya kehidupan.

Guru yang baik adalah guru yang mampu membelajarkan peserta didik melalui "proses pembelajaran yang interaktif, inspiratif, menyenangkan, menantang, memotivasi untuk atif dan kreatif, mandiri sesuai bakat, minat, dan perkembangan fisik dan psikologis peserta didik" (SNP, 2005) Salah satu usaha yang dilakukan guru adalah menjadi teladan dari manusia yang diinginkan tersebut. Guru harus menunjukan tanggung jawabnya menjadi guru yang tepat untuk membelajarkan peserta didik yang dari tahun ke tahun dihadapkan pada tuntutan perkembangan zaman yang berubah.

Pada generasi milenial ini, para peserta didik senantiasa memanfaatkan fasilitas informasi dan teknologi. Hal ini mendorong penulis untuk membuat media pembelajaran dengan memanfaatkan kemajuan teknologi. Salah satunya penggunaan media pembelajaran berupa pemanfaatan Video agar tercipta suasana penyampaian materi yang lebih menyenangkan bagi peserta didik. Dengan media pembelajaran berupa pemanfaatan Video, peserta didik dapat dengan mudah menerima informasi sehingga diharapkan dapat meningkatkan hasil pembelajaran secara optimal. Selain itu peserta didik juga dapat memutar kembali media video tersebut di luar lingkungan sekolah.

Mengingat pentingnya permasalah tersebut di atas, maka penulis memandang perlu untuk mengembangkan media pembelajaran untuk mata pelajaran IPA melalui media video dengan judul "Pemanfaatan Media Video dan Market Plan dalam Mata pelajaran IPA Pokok Bahasan Sistem Pencernaan Manusia untuk Meningkatkan Hasil Belajar”. Subjek penelitian peserta didik yang ada di lingkungan SDN Karangmulya 1. Pembahasan ini dipilih dengan alasan pertama, untuk mengungkapkan pemanfaatan media video dan metode pembelajaran market plan. Kedua, mengelola materi sistem pencernaan manusia pada mata pelajaran IPA di tingkat SD yang dikemas dalam bentuk audio visual dan metode market plan. Ketiga, untuk menunjukan hasil belajar dengan memanfaatkan media video dan metode pembelajaran market plan lebih efektif dan optimal.

Rumusan masalah dalam penelitian ini adalah sebagai berikut:

1. Bagaimana pemanfaatan media video dan metode pembelajaran market plan dalam kegiatan pembelajaran IPA pokok bahasan sistem pencernaan manusia di kelas VI?

2. Bagaimana mengelola materi pembelajaran IPA pokok bahasan sistem pencernaan manusia?

3. Bagaimana hasil belajar peserta didik kelas VI setelah mempelajari sistem pencernaan manusia dengan menggunakan media video dan metode pembelajaran market plan?

Tujuan dari penelitian ini adalah sebagai berikut:

1. untuk mendeskripsikan pemanfaatan media video dan metode pembelajaran market plan dalam pembelajaran IPA pada sub pokok bahasan sistem pencernaan manusia.

2. Untuk menjelaskan pengelolaan materi sistem pencernaan manusia pada mata pelajaran IPA di tingkat SD yang dikemas dalam bentuk video dengan menggunakan metode pembelajaran market plan.

3. Untuk membuktikan hasil belajar peserta didik kelas VI SDN Karngmulya 1 dalam mata pelajaran IPA pokok bahasan sistem pencernaan manusia dengan memanfaatkan media video dan 


\section{Gunahumas}

Jurnal Kehumasan

metode pembelajaran market plan

Penelitian ini memiliki manfaat yaitu:

1. Bagi Peserta didik

Memberikan pembelajaran yang mandiri, aktif, dan menyenangkan sehingga dapat memotivasi peserta didik agar lebih kreatif.

2. Bagi Guru

Guru dapat mengembangkan media pembelajaran yang efektif, efisien, berbobot, dan inovatif .

\section{KAJIAN LITERATUR}

Kata media berasal dari kata medium yang artinya perantara atau pengantar. Dengan demikian media pembelajaran dapat diartikan sebagai perantara sampainya pesan belajar dari sumber pesan kepada penerima pesan sehingga terjadi interaksi belajar mengajar (Munir, 2010: 138).

Menurut Iif Khoiru Ahmadi \& Sofan Amri, (2011: 145) menyatakan media adalah alat yang digunakan untuk menyalurkan pesan atau informasi dari pengirim kepada penerima pesan. Pengirim dan penerima pesan itu dapat berbentuk orang atau lembaga, sedangkan media tersebut dapat berupa alat-alat elektronik, gambar, buku, benda nyata, dan sebagainya.

Dari pengertian diatas, dapat disimpulkan bahwa media pembelajaran adalah alat yang digunakan untuk membantu peserta didik dalam menerima informasi pembelajaran sehingga diharapkan tujuan pembelajaran dapat tercapai.

(Munir, 2010: 138-139) manfaat media pembelajaran berbasis informasi dan teknologi yaitu:

a) Dapat memberikan pemahaman yang lebih dalam terhadap materi pembelajaran yang sedang dibahas karena dapat menjelaskan konsep yang sulit menjadi mudah atau sederhana.

b) Dapat menjelaskan materi pembelajaran yang abstrak menjadi konkrit.

c) Membantu pengajar menyajikan materi pembelajaran menjadi lebih mudah dan cepat sehingga peserta didikpun mudah memahami

d) Menarik dan membangkitkan perhatian, minat, motivasi, aktivitas, dan kreatifitas belajar peserta didik.

e) Peserta didik belajar sesuai dengan karakteristiknya, kebutuhan, minat, dan bakatnya.

f) Menghemat waktu, tenaga, dan biaya.

(Daryanto, 2012: 86) video merupakan suatu medium yang sangat efektif untuk membantu proses pembelajaran, baik untuk pembelajaran masal, individual, maupun berkelompok. Video juga merupakan bahan ajar noncetak yang kaya informasi dan tuntas karena dapat sampai ke hadapan siswa secara langsung.

(Rusman, 2012) video merupakan bahan pembelajaran tampak dengar (audio visual) yang dapat digunakan untuk menyampaikan pesan-pesan/materi pelajaran. Dikatakan tampak dengar karena unsur dengar (audio) dan unsur visual/video (tampak) dapat disajikan serentak.

Market plan adalah suatu metode pembelajaran berupa kegiatan di pasar, dimana peserta didik dapat melakukan aktifitas jual beli informasi pengetahuan, baik berupa konsep ataupun karya sesuatu. Informasi yang diperjualbelikan adalah materi yang dipelajari pada hari tersebut. Metode market plan ini mengandung nuturrant effect dalam pembentukan karakter secara direct, seperti bertanggung jawab membuat karya dan mempertahankan karyanya, kerjasama dalam kelompok, terbuka dengan kritikan pembeli, usaha kerja keras untuk menjadi yang terbaik, terbiasa mengevaluasi dan dievaluasi, dan membangun kemandirian. (Duduh Rusdiana, n.d.) 
Langkah-langkah pembelajaran market plan menurut Tri Eko Susilawati yaitu:

1. Guru memberikan materi kepada setiap kelompok.

2. Kelompok mendeskripsikan konsep materi boleh dalam bentuk mind mapping, gambar, tulisan, dan yang lainya dikertas karton.

3. Ketua kelompok membagi anggotanya menjadi dua yaitu yang sebagai penjual dan pembeli.

4. Anggota kelompok yang bertugas sebagai pembeli membeli pengetahuan ke kelompok lain secara urut, sedangkan anggota kelompok yang bertugas menjadi penjual wajib menerangkan setiap pembeli tentang materi yang ada di grupnya.

5. Setelah semua dikunjungi dan ada bukti kunjungan, anggota kelompok yang bertugas sebagai pembeli wajib menerangkan hasil belian materi kepada anggota kelompok yang bertugas sebagai penjual.

6. Presentasi kelompok menjelaskan semua materi dari semua kelompok.

7. Berikan penghargaan

(Triekosulistiowati, n.d.)

Sains atau IPA adalah ilmu pengetahuan yang sistematis yang mempelajari tentang alam dan dunia fisik; pengetahuan sistematis diperoleh dari observasi, penelitian, dan percobaan yang mengarah pada penentuan sifat dasar atau prinsip suatu pengetahuan yang sedang diselidiki, dipelajari, dan sebagainya (KBBI, 2008: 1202).

Dari pengetian diatas, dapat disimpulkan IPA adalah suatu ilmu pengetahuan yang mempelajari gejala-gejala alam sekitar yang meliputi benda, makhluk hidup, dan alam sekitar. Materi IPA yang digunakan dalam penelitian ini adalah tentang sistem pencernaan manusia.

Proses pencernaan makanan diawali pada bagian mulut. Di dalam mulut makanan dihaluskan oleh gigi dan kelenjar ludah. Kelenjar ludah menghasilkan air ludah dan enzim ptialin. Enzim merupakan zat yang berguna untuk menghancurkan makanan secara kimiawi menjadi bagian yang lebih halus.

Dari mulut makanan masuk menuju kerongkongan. Di dalam kerongkongan terjadi gerak peristaltik, yaitu gerakan meremas-remas yang dilakukan oleh dinding kerongkongan. Gerak peristaltik inilah yang menyebabkan makanan dapat masuk ke dalam lambung.

Di dalam lambung makanan yang sudah dihaluskan oleh gigi di dalam mulut akan dilumatkan dan diaduk dengan bantuan getah lambung. Getah lambung ini berguna untuk memecah makanan agar mudah diserap oleh pembuluh darah. Makanan yang telah dilumatkan di dalam lambung akan berupa bubur halus sehingga mudah diserap oleh usus. Makanan yang telah dicerna di dalam lambung kemudian masuk menuju usus dua belas jari. Di dalam usus dua belas jari ini pencernaan dibantu oleh getah pankreas dan getah empedu. Getah empedu dihasilkan oleh hati. Getah empedu digunakan untuk memecah lemak menjadi butiran-butiran yang sangat halus sehingga dapat membantu kerja enzim lipase. Getah pankreas dihasilkan oleh pankreas. Getah pankreas mengandung enzim amilase, tripsine, dan lipase. Amilase yang mengubah zat tepung menjadi gula. Tripsin, yang mengubah protein menjadi asam amino. Lipase, yang mengubah lemak menjadi asam lemak dan gliserol. Setelah itu, makanan disalurkan menuju usus halus. Di dalam usus halus makanan dicerna kembali sehingga terbentuklah sari-sari makanan. Sari-sari makanan inilah yang akan diserap oleh dinding-dinding usus halus melalui pembuluh darah sehingga masuk ke dalam darah untuk diedarkan ke seluruh tubuh. 


\section{Gunahumas}

Jurnal Kehumasan
Sisa makanan atau ampas makanan akan masuk ke dalam usus besar. Selanjutnya sisa makanan tersebut dibusukkan oleh bakteri menjadi kotoran. Kemudian, kotoran ini akan dikeluarkan dari tubuh melalui anus. Di dalam usus besar tidak terdapat penyerapan sari makanan melainkan hanya penyerapan air. (BSE kelas 5 SD, 2008 : 11).

Secara bahasa peserta didik adalah orang yang sedang berada pada fase pertumbuhan dan perkembangan baik secara fisik maupun psikis. Pertumbuhan dan perkembangan merupakan ciri dari seorang peserta didik yang perlu bimbingan dari seorang pendidik. (Madyawati, n.d.)

(Drs. H. Isjoni, 2009 : 36) Piaget mengelompokkan tahap perkembangan kognitif anak menjadi empat, yaitu: tahap sensorimotor (0-2 tahun), tahap praoperasional (2-7 tahun), tahap operasi kongkret (8-11 tahun), dan tahap operasional formal (diatas 11 tahun).

Berdasarkan penggolongan menurut Piaget, peserta didik kelas VI SD yang rata-rata berumur diatas 11 tahun tergolong pada tahap operasional formal. Pada tahap ini, peserta didik sudah mampu berpikir abstrak dan logis dengan menggunakan pola pikir.

Hasil belajar merupakan bagian terpenting dalam pembelajaran. (Nana Sudjana, 2009) mendefinisikan hasil belajar peserta didik pada hakikatnya adalah perubahan tingkah laku sebagai hasil belajar dalam pengertian yang lebih luas mencakup bidang kognitif, afektif, dan psikomotorik.

\section{METODE}

Pendekatan yang digunakan adalah mix metdhod yang menggunakan dua pendekatan yaitu kuantitatif dan kualitatif (Cresswell,2009). Menurut (Dr. Deni Darmawan, S.Pd., 2019 : 37) "penelitian kuantitatif adalah suatu proses menemukan pengetahuan yang menggunakan data berupa angka sebagai alat menemukan keterangan mengenai apa yang ingin kita ketahui".

Metodologi yang digunakan dalam inovasi pembelajaran yang penulis lakukan dapatlah dijelaskan sebagai berikut :

1) Identifikasi dan perumusan masalah Tahap ini, diidentifikasikan masalah yang dirasakan mengganggu pencapaian tujuan pembelajaran, kemudian dibentuk rumusan masalah.

2) Alternatif pemecahan, penyusun dan persiapan pembelajaran

Tahap ini, merupakan tahap pencarian berbagai alternatif yang dapat menjadi solusi dalam pemecahan masalah. Setelah diperoleh alternatif terbaik dilakukan penyusunan dan persiapan yang diperlukan pada proses pembelajaran.

3) Implementasi pembelajaran IPA melalui media video dan metode pembelajaran market plan.

Tahap ini merupakan proses inti dari semua kegiatan, Dimana proses pembelajaran berlangsung dan dilakukan pengamatan terhadap kegiatan yang dilakukan guru dan peserta didik melalui media video dan metode pembelajaran market plan.

4) Analisis

Hasil yang telah diperoleh dianalisis berdasarkan kriteria-kriteria yang telah ditentukan.

5) Refleksi

Setelah dianalisis, kemudian direfleksikan untuk mengevaluasi, mengoreksi dan perbaikan untuk siklus selanjutnya. Dari siklus pertama disimpulkan apakah siklus berjalan dengan baik atau tidak. Pada siklus selanjutnya dilakukan perbaikan berdasarkan analisis dan 
refleksi dari siklus sebelumnya. Demikian setiap siklus berlangsung.

\section{HASIL DAN PEMBAHASAN}

Pembelajaran yang memanfaatkan media video dan metode market plan sudah ujicobakan di kelas 6 SDN Karangmulya 1 melalui 2 siklus.

\section{Siklus I}

\section{1) Rencana}

Pada siklus satu ini disusun rencana pembelajaran dengan menggunakan media video dan metode pembelajaran market plan. Materi yang akan dipelajari peserta didik yaitu tentang sistem pencernaan manusia. Selanjutnya menyusun instrument penilaian berupa lembar evaluasi, lembar observasi, lembar wawancara, dan catatan lapangan.

\section{2) Deskripsi}

Pembelajaran siklus I dilaksanakan pada Senin, 21 Januari 2019. Pembelajaran pada siklus ini difokuskan pada usaha guru untuk menerapkan media pembelajaran dengan menggunakan video dan metode market plan pada materi sistem pencernaan manusia. Alokasi waktu yang digunakan 2 jam pelajaran selama satu kali pertemuan. Sesuai dengan rencana pembelajaran yang telah dibuat, kegiatan pembelajaran diawali dengan apersepsi dan motivasi yang bertujuan merangsang pengetahuan peserta didik terhadap materi yang akan dipelajari.

\section{3) Analisis}

Setelah kegiatan pembelajaran selesai, peneliti mengumpulkan semua instrument pengumpulan data yang disusun pada saat rencana penelitian. Setelah semua terkumpul peneliti bersama observer menganalisis tentang pelaksanaan kegiatan.

Hasil observasi yang diperoleh pada siklus 1 sebagai berikut:

a. Aktivitas peserta didik.
Pada saat penayangan materi dengan menggunakan media video, peserta didik cenderung pasif seolah-olah terbius dengan tampilan video. Sementara pada saat pembelajaran berlangsung dengan metode market plan, peserta didik cenderung hyperaktif.

b. Aktivitas guru

Pada Siklus I menunjukkan bahwa guru belum sempat menyampaikan tujuan pembelajarannya. Dalam mengelompokkan peserta didik tidak memperhatikan klasifikasi kemampuan peserta didik dalam arti bersifat homogen. Selama kegiatan pembelajaran berlangsung, guru berkeliling ke tiap-tiap kelompok untuk mengamati kegiatan peserta didik. Akhir dari kegiatan pembelajaran, guru bersama peserta didik menyimpulkan materi pelajaran dan memberikan tindak lanjut berupa pekerjaan rumah tentang alat-alat pencernaan manusia.

Dalam kegiatan wawancara bersama peserta didik diketahui bahwa 82,61\% peserta didik menyukai cara guru mengajar dan 34,78\% tidak menyukai cara guru mengajar. Sedangkan kesan terhadap teknik pembelajaran sebanyak $89,96 \%$ peserta didik menyukai dan $13,04 \%$ tidak menyukainya. Sementara kesan terhadap materi diperoleh sebanyak 56,52\% peserta didik menyukai materi sistem pencernaan manusia dan $44,48 \%$ peserta didik tidak menyukainya.

Dalam catatan lapangan, pengamatan terhadap aktivitas peserta didik, yaitu :

a. Pada pemahaman konsep, peserta didik seolah terbius dengan tayangan video.

b. Dalam pembelajaran dengan metode market plan, anggota kelompok yang berperan sebagai penjual kurang merespon pendapat dari anggota kelompok yang akan berperan sebagai pembeli. 
Evaluasi akhir menunjukan hasil yang diperoleh belum memenuhi kriteria ketuntasan minimal yang memperoleh rata-rata 60,65 sehingga perlu diadakan penelitian pada siklus selanjutnya.

\section{Siklus II}

1) Rencana

Pada siklus lanjutanpun diawali dengan penyusunan rencana pembelajaran menggunakan media video dan metode pembelajaran market plan. Sementara materi yang akan disajikan masih tentang sistem pencernaan manusia. Selanjutnya menyusun instrument penilaian berupa lembar evaluasi, lembar observasi, lembar wawancara, dan catatan lapangan.

2) Deskripsi

Pembelajaran pada siklus lanjutan ini, dilaksanakan pada Senin, 28 Januari 2019. Pembelajaran pada siklus ini difokuskan pada usaha guru untuk menerapkan media pembelajaran dengan menggunakan video dan metode market plan pada materi sistem pencernaan manusia. Alokasi waktu yang digunakan 2 jam pelajaran selama satu kali pertemuan. Sesuai dengan rencana pembelajaran yang telah dibuat. Karena ini merupakan siklus lanjutan maka kegiatan apersepsi pada pertemuan kedua untuk materi sistem pencernaan manusia berupa tanya jawab tentang manfaat dari alat-alat pencernaan manusia. Selanjutnya untuk merangsang motivasi belajar, peserta didik diajak bernyanyi.

\section{3) Analisis}

Setelah kegiatan pembelajaran selesai, peneliti mengumpulkan semua instrument pengumpulan data yang disusun pada saat rencana penelitian. Setelah semua terkumpul, peneliti bersama observer menganalisis tentang pelaksanaan kegiatan.

Hasil observasi yang diperoleh pada siklus 2 sebagai berikut:
a. Aktivitas peserta didik.

Pada siklus lanjutan ini, peserta didik mulai terbiasa memperhatikan dengan seksama tayangan video tentang materi sistem pencernaan manusia. Sementara pada saat pembelajaran berlangsung dengan metode market plan, peserta didik terjalin interaksi yang cukup baik antara anggota kelompok yang berperan sebagai penjual dan yang berperan sebagai pembeli.

b. Aktivitas guru

Pada Siklus ini tujuan pembelajaran sudah disampaikan pada awal kegiatan sebelum kegiatan apersepsi. Peserta didik dikelompokan secara heterogen. Selama kegiatan pembelajaran berlangsung, guru berkeliling ke tiaptiap kelompok sambil membawa catatan untuk mengamati kegiatan peserta didik. Guru juga ikut membantu kelompok yang merasa kesulitan dalam menyajikan produk (materi) kelomponya. Akhir dari kegiatan pembelajaran, guru bersama peserta didik menyimpulkan materi pelajaran dan memberikan tindak lanjut berupa pekerjaan rumah tentang macam-macam penyakit yang menyerang sistem pencernaan manusia.

Dalam kegiatan wawancara bersama peserta didik diketahui bahwa 100\% peserta didik menyukai cara guru mengajar. Sedangkan kesan terhadap teknik pembelajaran sebanyak 95,65\% peserta didik menyukainya dan $4,35 \%$ peserta didik tidak menyukai. Sementara kesan terhadap materi diperoleh sebanyak $86,96 \%$ peserta didik menyukai materi sistem pencernaan manusia dan $13,04 \%$ peserta didik tidak menyukainya.

Dalam catatan lapangan, pengamatan terhadap aktivitas peserta didik, yaitu :

a. Pada pemahaman konsep, peserta didik memperhatikan dengan seksama materi yang ditayangkan dengan media video. 
b. Dalam pembelajaran dengan metode market plan, setiap anggota bail yang berperan sebagai penjual dan pembeli sudah terjalin interaksi yang cukup baik.

Evaluasi akhir menunjukan hasil yang diperoleh sudah memenuhi kriteria ketuntasan minimal yaitu rata-rata 84,57. Sehingga tidak perlu dilakukan penelitian lanjutan.

Dengan demikian, jelaslah bahwa pembelajaran dengan mengkolaborasikan penggunakan media video dan metode market plan dapat meningkatkan hasil belajar peserta didik SDN KARANGMULYA 1dalam materi sistem pencernaan manusia.

Penelitian ini sudah diseminasikan kepada teman sejawat yang ada di lingkungan SDN Karangmulya 1 dan sedang dipublikasikan kepada rekan sejawat di lingkungan gugus Kadungora melalui kegiatan KKG.

\section{SIMPULAN}

Berdasarkan penelitian dan pembahasan pada bab sebelumnya dapat disimpulkan bahwa :

1. Kolaborasi dari pemanfaatan media video dan metode pembelajaran market plan dalam pembelajaran IPA pokok bahasan sistem pencernaan manusia di kelas VI dapat membantu peserta didik dalam menyerap materi pembelajaran.

2. Pengelolaan materi pembelajaran IPA pokok bahasan sistem pencernaan manusia tidak verbalisme sehingga diharapkan kemampuan mengingat materi sistem pencernaan manusia pada peserta didik lebih tahan lama.

3. Hasil belajar peserta didik kelas VI SDN karangmulya 1 setelah mempelajari sistem pencernaan manusia dengan menggunakan media video dan metode pembelajaran market plan menunjukan hasil yang optimal.
Berdasarkan pembahasan tentang "Pemanfaatan Media Video dan Market Plan dalam Mata Pelajaran IPA Pokok Bahasan Sistem Pencernaan Manusia untuk Meningkatkan Hasil Belajar", saran yang dapat penulis sampaikan, guru hendaknya selalu melakukan pembaharuan-pembaharuan baik dari segi media ataupun metode untuk mengembangan kegiatan belajar mengajar agar dapat meningkatkan hasil belajar peserta didik.

\section{DAFTAR PUSTAKA}

Daryanto. (2012). Media Pembelajaran. PT. Sarana Tutorial Nurani Sejahtera.

Dr. Deni Darmawan, S.Pd., M. S. (2019). Metode Penelitian kuantitatif (P. Latifah (Ed.); keempat). PT. Remaja Rosdakarya.

Drs. H. Isjoni. (2009). Cooperative Learning (kedua). Alfabeta.

Duduh Rusdiana. (n.d.). Market Plan Action.

Iif Khoiru Ahmadi, M. P., \& Sofan Amri, S. P. (2011). Paikem Gembrot (Drs. Hendro Ari Setyono (Ed.); pertama). Prestasi Pustaka.

Madyawati. (n.d.). Pengertia Peserta Didik. In Wordpress.com.

Munir. (2010). Kurikulum Berbasis TIK. Alfabeta.

Nana Sudjana. (2009). Penilaian Hasil Belajar Mengajar. Remaja Rosda Karya.

Rusman. (2012). Belajar dan Pembelajaran Berbasis Komputer. Penerbit Alfabeta.

SNP. (2005). PP Nomor 19 Tahun 2005 tentang Standar Nasional Pendidikan. In Evaluation. https://doi.org/10.1103/PhysRevB.6 6.085421

Triekosulistiowati. (n.d.). Langkahlangkah pembelajaran market plan.

UU Sisdiknas Pasal 3 UU No. 20 tahun2003. (2003). 
Gunahumas

p-ISSN: 2338-1507

Jurnal Kehumasan

Vol 3, No 2, 2020, 25-34 